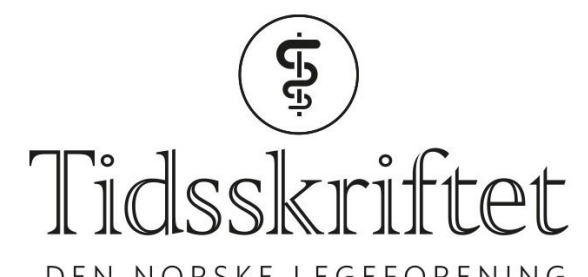

DEN NORSKE LEGEFORENING

\title{
Effektive legemidler mot malaria
}

FRA ANDRE TIDSSKRIFTER

ØYVIND STOPLE SIVERTSEN

Tidsskriftet

Nye kombinasjonspreparater mot malaria er like effektive som etablerte kombinasjonspreparater. Det viser en ny studie.

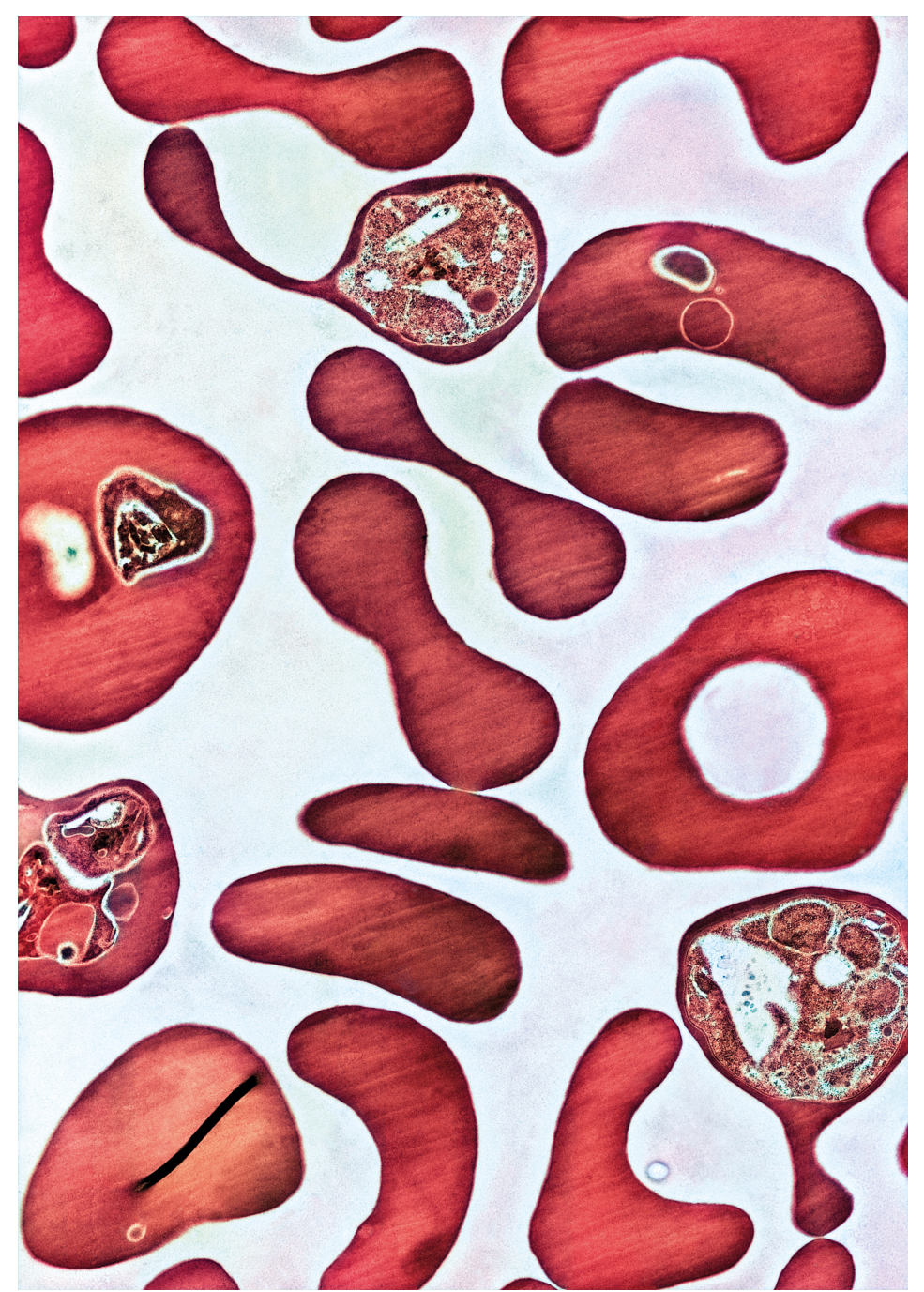

Røde blodceller infisert med malariaparasitter. Illustrasjonsfoto: Science Photo Library/NTB scanpix

De siste tiårene er det kommet flere typer legemidler mot malaria, bl.a. artesunat. Artesunat er svært effektivt, men har så kort halveringstid at det alltid må gis i kombinasjon med et annet legemiddel. 
I en studie som nylig er publisert i The Lancet, ble 4710 pasienter med ukomplisert malaria i to land i Vest-Afrika randomisert til fire grupper som fikk behandling med to nye eller to etablerte artesunatbaserte kombinasjonspreparater (1). Begge de nye

kombinasjonspreparatene, pyronaridine-artesunat og dihydroartemisinin-piperakin, viste seg å være like effektive som de eksisterende alternativene, artemeter-lumefantrin og artesunat-amodiakin ved oppfølging etter 42 dager og etter to år.

- Denne studien viser at man nå har flere effektive artesunatbaserte kombinasjonspreparater å velge mellom i høyendemiske Vest-Afrika, noe som er gunstig med tanke på resistensutvikling og potensielle bivirkninger, sier Kristine Mørch, overlege ved Infeksjonsseksjonen, Medisinsk avdeling, Haukeland universitetssykehus, og leder av Kompetansetjenesten for tropiske infeksjonssykdommer.

- Resistens mot artesunat og kombinasjonspreparater er ikke vanlig i Afrika, og en mulig spredning av slik resistens fra Asia vil få katastrofale konsekvenser, sier Mørch.

Hun får støtte i dette av sin kollega, Frank O. Pettersen, som er leder for Regional kompetansetjeneste i import- og tropesykdommer, og overlege ved Infeksjonsavdelingen, Oslo universitetssykehus, Ullevål. Foruten å understreke at studien er viktig, påpeker han at eksisterende, sesongbasert forebyggende malariabehandling til barn under fem år i Sahelregionen av Vest-Afrika inneholder amodiakin.

- Dette innebærer at kombinasjonsbehandlingen artesunat-amodiakin ikke bør brukes. De nye kombinasjonspreparatene er tatt med på listen til Verdens helseorganisasjon over essensielle medisiner og bør bli tilgjengelige i endemiske områder, sier Pettersen.

\section{LITTERATUR:}

1. West African Network for Clinical Trials of Antimalarial Drugs (WANECAM). Pyronaridineartesunate or dihydroartemisinin-piperaquine versus current first-line therapies for repeated treatment of uncomplicated malaria: a randomised, multicentre, open-label, longitudinal, controlled, phase 3b/4 trial. Lancet 2018;391: 1378 - 9o. [PubMed][CrossRef]

Publisert: 26. juni 2018. Tidsskr Nor Legeforen. DOI: 10.4045/tidsskr.18.0425

(C) Tidsskrift for Den norske legeforening 2020. Lastet ned fra tidsskriftet.no 